\title{
The influence of maternal size on placental area and foal birthweights in the mare
}

\author{
Sandra Wilsher, Melanie Ball and W.R. Allen \\ University of Cambridge, Department of Clinical Veterinary Medicine Equine Fertility Unit, Mertoun Paddocks, Newmarket, Suffolk, U.K.
}

\begin{abstract}
Summary
The influence of maternal size on foal birthweights and the total microscopic area of fetomaternal contact at the placental interface was studied by comparing placentae from normal Thoroughbred-in-Thoroughbred and Pony-in-Pony control pregnancies with those from betweenbreed Thoroughbred-in-Pony (deprived in utero environment) and Pony-in-Thoroughbred (luxurious in utero environment) pregnancies created by embryo transfer. Strong positive correlations were revealed between foal birthweight and both the gross area of the placenta and the total microscopic area of fetomaternal contact via the microcotyledons. The results highlight the importance of the intrauterine environment for the growth and development of the equine fetal foal.
\end{abstract}

Keywords: $\quad$ Mare, placenta, embryo transfer, birthweights

\section{Der Einfluß der mütterlichen Körpergröße auf die Plazentafläche und Fohlen-Geburtsgewichte beim Pferd}

Es wurde der Einfluß der mütterlichen Körpergröße auf die Fohlen-Geburtsgewichte und die mikroskopische Gesamtfläche des fetomaternalen Kontakts an Plazenten von normalen Vollblut in Vollblut- und Pony in Pony-Graviditäten als Kontrolle im Vergleich zu Trächtigkeiten von Vollblut in Pony-Paarungen (armes intrauterines Milieu) und Pony in Vollblut (reiches intrauterines Milieu) untersucht. Engste positive Korrelation wurden ermittelt zwischen Fohlen-Geburtsgewichten und jeweils der anatomischen und mikroskopischen Plazentafläche mit fetomaternalem Kontakt über die Mikrokotyledonen. Diese Ergebnisse belegen eindeutig die Bedeutung des intrauterinen Milieus für das Wachstum und die Entwicklung des equinen Föten.

Schlüsselwörter: Stute, Plazenta, Embryo-Transfer, Geburtsgewicht

\section{Introduction}

In mammals the placenta is the vehicle for nutritional and gaseous exchange between the maternal and fetal circulations during pregnancy. The allantochorionic placenta of equids is classified as non-deciduate, non-invasive, epithelichorial and diffuse and maternofetal contact for the purposes of haemotrophic transfer occurs over virtually the entire surface of the chorion (Amoroso, 1952). During the first 40 days of gestation the trophoblast lies unattached in close but simple apposition to the uterine lumenal epithelium (van Niekerk and Allen, 1975). Attachment occurs gradually after this time and involves transformation of the initially very simple and rudimentary macrovilli into branched and highly complex villi which interdigitate with equivalent elongated villi of maternal endometrium to form the haemotrophic exchange units of the mature placenta known as microcotyledons (Samuel et al., 1974). Development of the microcotyledons is essentially complete by day 150 of gestation when the outermost surface of the allantochorion is now covered in tens of thousands of microcotyledons, each around 1-2 $\mathrm{mm}$ in diameter when mature. They can be readily observed with the naked eye and they give this maternal surface of the chorion a red, roughened velvety appearance. Microscopically, their intricate, branching, aborescent structure is apparent and, in addition, the trophoblast epithelium covering each macrovillus of the cotyledon exhibits a close microvillous junction with the lumenal surface of the opposing endometrial epithelium, thereby further in- creasing the area available for haemotrophic absorption (Samuel et al., 1975).

As a result of the competition of their diffuse placentae for the limited area of endometrium within the uterus, the majority of twin conceptuses in the mare are aborted during the second half of gestation due to nutritional deprivation causing the death of the more disadvantaged of the two fetuses (Prickett, 1970; Jeffcott and Whitwell, 1973). Steven (1982) summarised the situation when he described the equine placenta „as an organ geared to the production of a single offspring." Maternal size has been shown to exert a profound effect on the birthweight of the foal Walton and Hammond, 1938; Tischner, 1987) and correlations between placental area and birthweight have been noted by various authors. For example, Rossdale (1966) reported that the birthweight of Thoroughbred foals is directly proportional to the gross surface area of their placenta and Bracher et al (1996) demonstrated a close correlation between the age of the mare, the health of her endometrium, the density and regularity of the microcotyledons per area of placenta and fetal growth during the first two thirds of gestation. And in other studies, a reduction in the absorptive potential of the placenta has been shown to lead to small-for-dates babies in women (Pivalizza et al, 1990), and fetal growth retardation in sheep (Alexander, 1974; McDonald et al., 1981).

In the present study, computer-aided morphometric analysis was used to measure the surface density of microcoty- 
ledons, or surface area of fetomaternal contact, per area of placenta at term. By multiplying this figure by the displacement volume of the allantochorion, the total surface area of fetomaternal contact achieved by the placenta was calculated. The method was then used to compare the area of fetomaternal contact in term placentae recovered from Pony and Thoroughbred mares carrying, respectively, withinbreed Pony and Thoroughbred foals or, respectively, between-breed Thoroughbred or Pony foals following embryo transfer. In this manner it was intended to study the influence of maternal size on both the extent of development and the exchange competence of the placenta.

\section{Materials and methods}

\section{Recovery and gross measurement of placentae}

Placentae were recovered at spontaneous third stage labour from 11 Thoroughbred-in-Pony and 7 Pony-inThoroughbred pregnancies created by embryo transfer, and from 6 Thoroughbred-in-Thoroughbred and 7 Pony-inPony control pregnancies created by artificial insemination. The amnion and umbilical cord were cut from the allantochorion as close as possible to the allantoic surface and discarded. The allantochorion was then weighed and laid flat on a large formica-covered board roughly in an F configuration, with the gravid and non-gravid horns forming the horizontal arms and the body forming the vertical arm of the F (see Fig. 1a; Asbury and LeBlanc, 1992; Schlafer, 1996). The allantochorion was dissected along one edge and opened out to lay flat on the board with the maternal or microcotyledonary surface uppermost (Fig. 1b). A large sheet of clear perspex, marked in a $10 \mathrm{~cm}^{2}$ grid pattern with small holes drilled at the intercepts of the lines, was supported directly above the flattened placenta. The total surface area was then calculated by counting the number of holes positioned above placental tissue and multiplying the figure by 100 . Ten random biopsy sites were selected by dropping a cocktail stick vertically through every nth hole overlying the placenta, where $n$ equalled the number of holes above placental tissue divided by 10 . Finally, the volume of the allantochorion was measured by submerging it in a large graduated measuring cylinder half filled with water and noting the volume displaced.

\section{Morphometric analysis}

The 10 random biopsies of allantochorion were fixed in $10 \%$ formol saline, processed, embedded in paraffin wax and sectioned at $5 \mu \mathrm{m}$ thickness. The sections were then stained with haematoxylin and eosin $(H$ \& E) and examined at 100X magnification under a Lietz Laborlux light microscope to which a digital stereology computer package (Digital Stereology 2.5, Confocal Technologies Ltd., Liverpool, UK.) was attached, to give an unbiased estimation of 3-D parameters from 2-D sections. In this instance, surface density was utilised to establish an estimate of surface area of features per unit volume of the reference space. Because surface area is reduced to profile boundary in sectioned samples, the software package used an estimator to count the intersections between the profiles of interest and geometric probes of the appropriate orientational distribution. Five estimations were made on each of the 10 random biopsies to give a total of 50 estimations for each placenta. All these estimates were averaged by the computer and presented as a value of surface density $\mu m^{-1}\left(\mu m^{2} / \mu m^{3}\right)$. This figure was then multiplied by the volume of the allantochorion to give a value for the total area of fetomaternal contact via the microcotyledons.

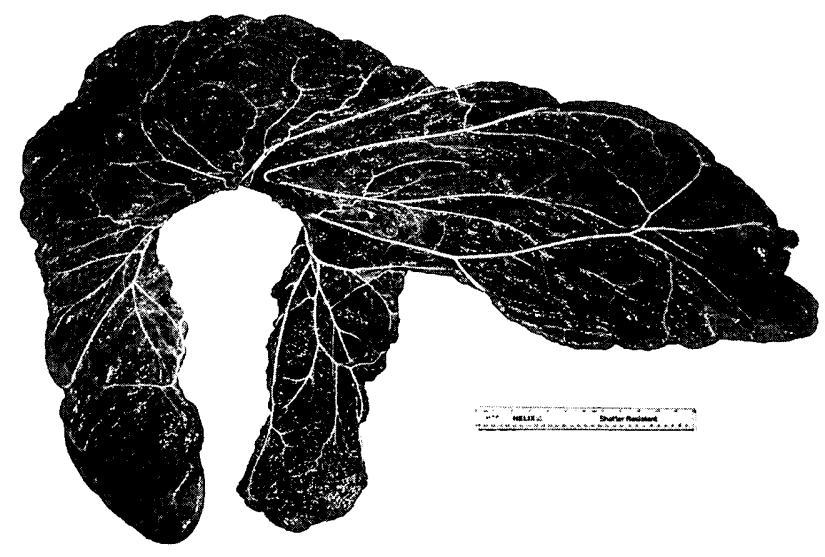

Fig. 1a: Intact Thoroughbred-in-Thoroughbred placenta with the fetal surface outermost laid out in the typical $F$ configuration to show the body and the gravid and non-gravid horns.

Intakte Vollblut-in-Vollblut Plazenta mit der nach aussen gewendeten fetalseitigen Oberfläche und in typischer FForm ausgelegt zur Demonstration des graviden und nichtgraviden Uterushorns.

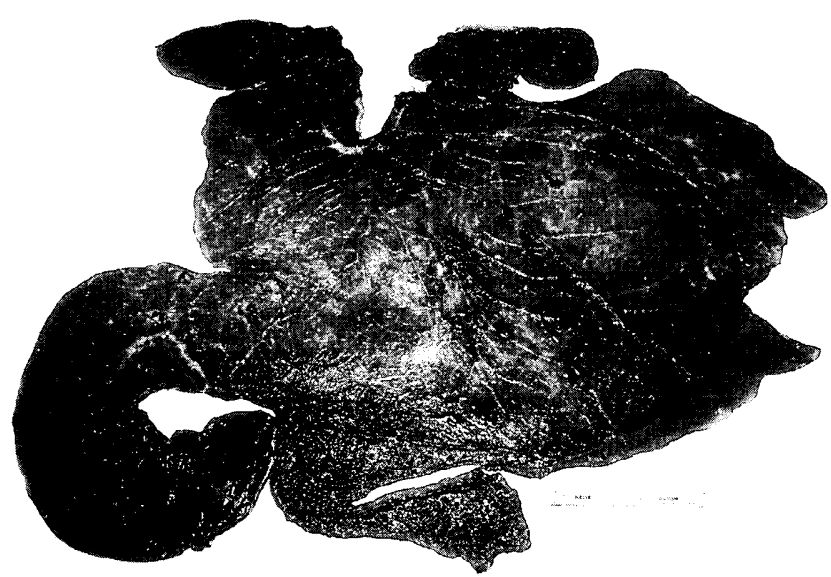

Fig. 1b: The same placenta dissected along one edge and opened out to show the maternal microcotyledonary surface.

Dieselbe Plazenta an einer Seite eröffnet zur Demonstration der maternalen Mikrokotyledonen-Oberfläche

\section{Results}

Mean placental weight, placental volume, gross placental area and foal birthweight were all highest in Thoroughbred 
foals born from Thoroughbred mares, followed by Pony foals from Thoroughbred mares, Thoroughbred foals from Pony mares and, finally, Pony foals from Pony mares. In addition, computer-aided morphometric measurement of the microscopic area of fetomaternal contact within the placental microcotyledons showed that surface density (surface area of interest/ reference volume) was arranged similarly within the groups, with the values being highest in the Thoroughbred-in-Thoroughbred and lowest in the Pony-inPony placentae. Multiplying this surface density figure by placental volume to give a value for total fetomaternal contact across the entire allantochorion, gave the same arrangement across the 4 types of pregnancy (i.e. Tb-in- $\mathrm{Tb}>$ $\mathrm{P}$-in-Tb $>\mathrm{Tb}$-in-P $>\mathrm{P}$-in-P). Furthermore, there was a strong bona fide correlation between birthweight of the foals and total fetomaternal contact area across the allantochorion (Fig. 2).

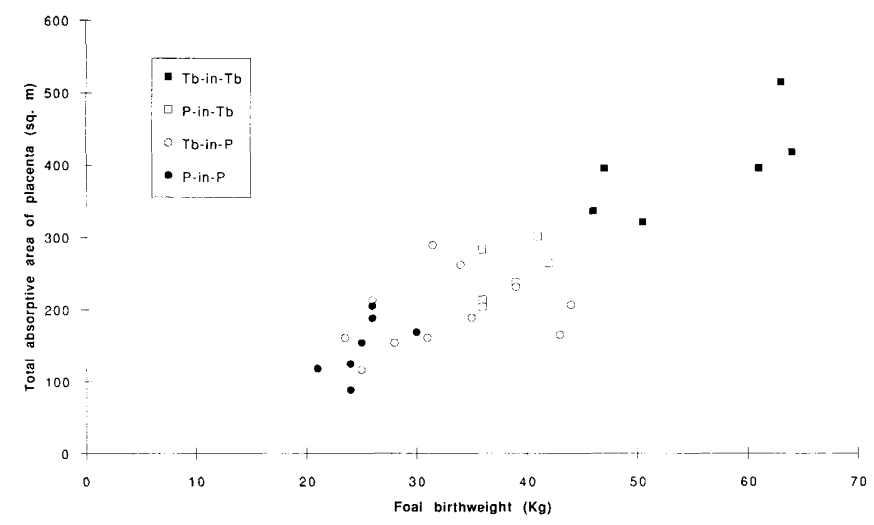

Fig. 2: Relationship between foal birthweights and the total haemotrophic absorptive area of the placenta at term. Note that the P-in-Tb foals which developed in the 'luxurious' uterine environment of the larger mares were born bigger and had greater total absorptive areas of their placentae than the $\mathrm{Tb}$-in- $P$ foals which developed in the 'deprived' uterine environment of the smaller Pony mares.

Beziehung zwischen fötalem Geburtsgewicht und der hämotroph-absorptiven Gesamtfläche der Plazenta zum Geburtstermin. Beachte, dass die P-inTb (Pony-in-Vollblut) Fohlen, die sich im luxuriösen uterinen Milieu entwickelten, zur Geburt größer waren und über eine größere absorptive Plazentagesamtfläche verfügten als Fohlen, die in eingeschränkter uteriner Umgebung der kleinen Ponystuten heranwuchsen.

\section{Discussion}

In their classical and revolutionary study involving the use of artificial insemination to reciprocally cross Shire horses with Shetland ponies - the biggest with the smallest in terms of the many and diverse breeds of horses - Walton and Hammond (1938) demonstrated the remarkable ability of the mare to limit, by controlling the area of the placenta available for fetomaternal exchange, the in utero growth of her foal in order to minimise the chances of dystocia and ensure a normal, uncomplicated birth at term. The foal born from the Shetland pony was approximately half the size of its reciprocal cross born from the much larger Shire mare and, very significantly, this great difference between the two persisted into adulthood. This was the first scientific evidence in support of a phenomenon that has been witnessed by horse breeders for centuries past. Namely, the lifelong effects of the reduction in expected birth size or 'runting' which occurs commonly in young, primiparous mares carrying their first foals, in the small percentage of mares that manage to carry viable twins to term (Jeffcott and Whitwell, 1976), and in older mares suffering extensive age-related degenerative changes in their endometrium (endometrosis; Bracher et al., 1996). In all three of these examples, the runting of the foal is occasioned by a reduction in the total area of healthy endometrium-allantochorion attachment during gestation causing a shortfall in the nutritional requirements to maximise the growth potential of the foal in utero.

Tischner (1987) made a further significant advance in our appreciation of the effects of maternal size on birthweights and subsequent growth of the foal when he used embryo transfer to create 3 pairs of sex-matched full-sibling Konik pony foals, one of which was gestated in its true genetic Pony mother while the other was transferred as an embryo to, and was carried to term by, a much larger draft-type mare. All three of these transferred foals were born taller and heavier then their respective siblings and the size differences became even more exaggerated during the first 6 months of life while they were nursing from their large surrogate, or smaller true, genetic dams (Tischner, 1987).

Our present study was something of mixture and an extension of these two earlier experiments of Walton and Hammond (1938) and Tischner (1987). Like Tischner (1987), we used embryo transfer, rather than cross-breeding, to make a relatively 'luxurious' in utero and post natal environment for the Pony foals transferred to the much larger Thoroughbred mares. And like Walton and Hammond (1938), we created the opposite scenario of deprivation by nutritional limitation for the Thoroughbred foals transferred to the Pony mares. In parallel with the earlier findings, we achieved considerable increases in height and weight compared to controls in the Ponies carried by the Thoroughbred mares and we induced appreciable down-sizing or runting in the otherwise healthy and vigorous Thoroughbred foals born spontaneously and without complication from the smaller Pony mares.

The findings of this experiment are clear-cut and are of practical interest to horse breeders. The very strong positive correlations exhibited by all three placental parameters measured - weight, gross area and total fetomaternal contact area of the allantochorion - with the weights of both the mare and the foal demonstrate convincingly that the growth of the fetal foal in utero is governed completely by 'real' placental size and competence which, in turn, is controlled equally strictly, by the area of healthy endometrium that is available for the placenta to attach to. Thus, the bigger the uterus, the bigger the placenta, the bigger the foal. And, conversely, the smaller the uterus, the smaller the endometrium and the greater the degree of runting which may be imposed upon the foal if the area of real placental 
exchange falls below genetic expectations. Thus, breeders should take careful account of both the endometrial health of the mare and the relative size of the mating stallion when planning their horse breeding programmes.

\section{Literature}

Alexander, G. (1974): Birthweight of lambs: Influences and consequences. In: CIBA Foundation Symposium 27 ' Size at Birth'. Eds: K. Elliott and J. Knight. Elsevier, Amsterdam. 215-239.

Amoroso, E.C. (1952): Placentation. In: Marshall's Physiology of Reproduction, Vol. II. Ed. A.S. Parkes, Longmans Green, London. 127-297.

Asbury, A.C. and LeBlanc, M.M. (1993): The placenta. In: Equine Reproduction. Eds. A.O. McKinnon and J.L. Voss, Lea and Febiger, Philadelphia. 509-516

Bracher, V., Mathias, S. and Allen, W.R. (1996): Influence of chronic degenerative endometritis (endometrosis) on placental development in the mare. Equine vet. J. 28, 180-188.

Jeffcott, L.B. and Whitwell, K.E. (1973): Twinning as a cause of foetal and neonatal loss in the Thoroughbred mare. J. comp. Path. 83, 91-105.

McDonald, I., Robinson, J.J. and Fraser, C. (1989): Studies on reproduction in prolific ewes. 7. Variability in the growth of individual foetuses in relation to intra-uterine factors. J. agric. Sci.. Camb. 96, 187-194.

Pivalizza, P.J., Woods, D.L., Sinclair-Smith, C.L., Kaschula, R.O.C. and Pivalizza, E.G. (1990): Placentae of light-for-dates infants born to underweight mothers at term: A morphometric study. Placenta 11, 135-142.

Prickett, M.E. (1970): Abortion and placental lesions in the mare. J. Am. vet. med. Ass. 157, 1465-1470.

Rossdale, P.D. (1966): A clinical and laboratory assessment of the health status of the newborn Thoroughbred foal. Fellowship thesis, Royal College of Veterinary Surgeons.

Samuel, C.A., Allen, W.R. and Steven, D.H. (1974): Studies on the equine placenta. I. Development of the microcotyledons. J. Reprod. Fert. 41, 441-445.

Samuel, C.A., Allen, W.R. and Steven, D.H. (1975): Ultrastructural development of the equine placenta. J. Reprod. Fert., Suppl. 23, 575-578.
Schlafer, D.H. (1996): The equine placenta before and after birth: Recognition of normal features and appreciation of lesions of clinical importance. Society for Theriogenology. Proceedings of the Mare Reproduction Symposium, Kansas City, Missouri, 122-137.

Steven, D.H. (1982): Placentation in the mare. J. Reprod. Fert., Suppl. 31, 41-55.

Tischner, M. (1987): Development of Polish pony foals born after transfer to large mares. J. Reprod. Fert., Suppl. 35, 705-709.

van Niekerk, C.H. and Allen, W.R. (1975): Early embryonic development in the horse. J. Reprod. Fert., Suppl. 23, 495-498.

Walton, A. and Hammond, J. (1938): The maternal effects on growth and conformation in Shire horse-Shetland pony crosses. Proc. Roy. Soc., Series B. 125, 311-335.

\section{Acknowledgements}

This study was sponsored by the Horserace Betting Levy Board (Project No 653) and the Thoroughbred Breeders' Association. We are grateful to Drs. Paul Sibbons and Tahera Ansari of Northwick Park Medical Research Centre, London for expert advice with the placental morphometry calculations, Dr. T.A.E. Stout of Cambridge Veterinary School for assistance with the embryo transfers, and Mr. Edward Sears for help with the foalings.

\section{Sandra Wilsher,}

Melanie Ball

W.R. Allen

University of Cambridge

Department of Clinical Veterinary Medicine

Equine Fertility Unit,

Mertoun Paddocks

Woodditton Road

Newmarket

Suffolk, CB8 9BH

U.K.

tel.: $0044-1638-662491$

fax: $0044-1638-667207$ 